Open Access

Res. Agric. Livest. Fish.

Research Article

Vol. 2, No. 3, December 2015: 385-394

\title{
EFFECT OF DIFFERENT DOSES OF IPIL-IPIL (Leucaena leucocephala) (LAM.) DE WIT. TREE GREEN LEAF BIOMASS ON RICE YIELD AND SOIL CHEMICAL PROPERTIES
}

\author{
Niloy Paul, Mohammad Kamrul Hasan ${ }^{*}$ and Md. Nasir Uddin Khan
}

Department of Agroforestry, Faculty of Agriculture, Bangladesh Agricultural University, Mymensingh-2202, Bangladesh

*Corresponding author: Mohammad Kamrul Hasan, E-mail: mkhasanaf@gmail.com

\section{ARTICLE INFO ABSTRACT}

Received

12.08 .2015

Accepted

07.12 .2015

Online

21.12.2015

Key words

Ipil-Ipil

Leaf biomass

Fertilizer

Rice

Yield
A field experiment was conducted to find out the effect of different doses of ipil-ipil (Leucaena leucocephala) (Lam.) de Wit. tree green leaf biomass on rice yield and soil chemical properties. Four different treatments such as $T_{0}$ : Recommended fertilizer dose (Urea $195 \mathrm{~kg} / \mathrm{ha}$, TSP $50 \mathrm{~kg} / \mathrm{ha}$, MOP $142 \mathrm{~kg} / \mathrm{ha}$, Gypsum $75 \mathrm{~kg} / \mathrm{ha}$ and Zinc Sulphate 4 $\mathrm{kg} / \mathrm{ha}$ ), $T_{1}: 5 \mathrm{t} / \mathrm{ha}, T_{2}: 7.5 \mathrm{t} / \mathrm{ha}$, and $T_{3}: 10 \mathrm{t} / \mathrm{ha}$ ipil-ipil tree green leaf was used in this study in a Randomized complete block design with three replications. The results showed that the treatment $T_{3}$ was performed better than recommended fertilizer dose in case all yield contributing characters of rice except grain yield. The highest ( $5.29 \mathrm{t} / \mathrm{ha})$ rice grain yield was obtained in recommended fertilizer dose followed by $10 \mathrm{t} / \mathrm{ha}, 7.5 \mathrm{t} / \mathrm{ha}$ and $5 \mathrm{t} / \mathrm{ha}$ ipil-ipil tree green leaf biomass amendment having $4.80,3.16$ and $2.36 \mathrm{t} / \mathrm{ha}$ respectively. The highest grain yield that was obtained from recommended fertilizer dose was $10.21 \%$ higher compared to the highest dose ( $10 \mathrm{t} / \mathrm{ha}$ ) of ipil-ipil tree green leaf biomass. It was mentioned that among the different doses of ipil-ipil tree green leaf biomass $10 \mathrm{t} /$ ha performed the best over others. The ipil-ipil tree green leaf biomass was also significantly influenced on some essential nutrient status which is very important for rice production. The highest amount of total $\mathrm{N}$, available $\mathrm{P}$, exchangeable $\mathrm{K}$ and available $\mathrm{S}$ were found in the treatment $\mathrm{T}_{3}$ and the lowest in the treatment $T_{1}$. Therefore, it can be concluded that the ipil-ipil tree leaf has beneficial effects and could be combined with inorganic fertilizer for sustainable crop yield and maintaining soil fertility.

To cite this article: Paul N, MK Hasan and MNU Khan, 2015. Effect of different doses of ipil-ipil (Leucaena leucocephala) (Lam.) de Wit. tree green leaf biomass on rice yield and soil chemical properties. Res. Agric. Livest. Fish. 2 (3): 385-394.

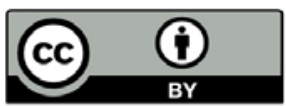

This is an open access article licensed under the terms of the Creative Commons Attribution 4.0 International License

www.agroaid-bd.org/ralf, E-mail: editor.ralf@gmail.com 


\section{INTRODUCTION}

Agriculture is the most important sector of the economy of Bangladesh. Rice (Oryza sativa L.) is the leading cereal crop in the world and staple food crop in Bangladesh. Agriculture in Bangladesh is dominated by intensive rice cultivation. Generally, crop production is a combined impact of soil factors, management and environmental factors. But soil varies considerably in their inherent capacity to supply nutrients, which are gradually declining over time due to intensive cropping with high yielding rice varieties. Nitrogen, phosphorus and potassium are the primary macronutrients and can play a key role to increase the production of rice to a great extent. For crop production, presence of organic matter in soil is important. Plant residues in any agricultural system are an important source of carbon and nutrient for the growth of crops. Organic resources play an essential role in soil fertility management in the tropics by their short-term effects on nutrient supply and longer-term contribution to soil organic matter formation (Palm et al., 2001). A good soil should have organic matter content of more than 3.5\%. But in Bangladesh, most of the soils have less than $1.7 \%$ and some soils have even less than $1 \%$ organic matter (Sattar, 2002). In Bangladesh about $60 \%$ of arable soils have below $1.5 \%$ organic matter whereas a productive mineral soil should have at least $2.5 \%$ organic matter (Rijpma and Jahiruddin, 2004) and the decreasing trend of soil organic matter is continuing. Organic matter depletion is observed in 7.5 million ha of land and declining soil fertility affects 5.6-8.7 million hectares of land (BARC, 2000). However, the traditional approach to soil fertility restoration through spontaneous regeneration of vegetation is coming under pressure due to the expansion of cropland. Soil fertility can be improved by employing agroforestry principles of incorporating organic inputs into the soil.

Agroforestry practices, especially evergreen agriculture and conservation agriculture with trees have emerged as sustainable measures of addressing land degradation and loss of soil fertility (Mwase et al., 2015). In increasing crop productivity for a sustainable crop production, soil quality has to be restored through a sustainable and intensified form of soil fertility amendments such as biomass transfer technology. In the biomass transfer technology, green manure is mulched or incorporated into agricultural soils. The advantage of this technology is that it allows for continuous cultivation as the incorporated green manure provides sustained soil nutrient replenishment (Place et al., 2003). Typically, Tithonia diversifolia, Leucaena leucocephala, Senna spectabilis, Gliricidia sepium, and Tephrosia vogelii are the most prominent tree species used in biomass transfer systems (Place et al., 2003). Green leaf biomass of leguminous tree such as Ipil-Ipil (Leucaena leucocephala) can help to restore soil fertility. Ipil-ipil tree leaf contains nitrogen $20.9 \mathrm{~kg}$ to $43.0 \mathrm{~kg}$, magnesium $3.9 \mathrm{~kg}$ to $10 \mathrm{~kg}$, calcium $7.5 \mathrm{~kg}$ to $20.3 \mathrm{~kg}$, phosphorus $1.5 \mathrm{~kg}$ to $4.0 \mathrm{~kg}$ and potassium $13.4 \mathrm{~kg}$ to $40.0 \mathrm{~kg}$ in per ton of dry leaves (Gordon and Wheeler, 1983). Ipil-ipil tree green leaf biomass can add these nutrients to the soil after decomposition process.

In Bangladesh the total dependence on inorganic fertilizers for crop cultivation is a common phenomenon. That is why the fertility of soils is declining day by day creating a major problem for agriculture. But there are little efforts to solve the problem. Therefore, it is necessary to examine the effect of different sources of organic fertilizers like tree leaf biomasses over inorganic fertilizers on crop yield for sustainable crop production and soil conservation. Several studies have been investigated on various aspects of tree leaf biomasses and their effects on crop yield and subsequent soil health throughout the world and in Indian sub-continent by many more researchers. Some studies on various tree leaf biomasses and their effects on crop growth and soil properties have been carried out by Haque et al. (2001), Uddin (2004), Ansari (2006), Hossain et al. (2007), Hasan et al. (2007), Dil Atia Parvin et al. (2007), Mondol et al. (2007), Mojumder et al. (2008), Khan (2009), Sarker et al. (2010), Tanzi et al. (2012), Arifin et al. (2012), Hasan (2014) in Bangladesh. However, the effects of ipil-ipil tree leaf biomass on rice yield and soil health is still in small pockets. Therefore, it thought necessary to determine the effect of ipil-ipil tree green leaf biomass on rice yield and soil chemical properties. Keeping in view of the above aspects the study was undertaken to examine the effect of different doses of ipil-ipil tree green leaf biomass added to the soil at pre-cultivation stage on the yield and yield contributing characters of transplant aman rice, and also on soil chemical properties. 


\section{MATERIALS AND METHODS}

The experiment was carried out at the Agroforestry Farm, Department of Agroforestry, Bangladesh Agricultural University, Mymensingh during aman season from August-December 2014. The experimental area experiences a sub-tropical climate and belonged to Old Brahmaputra Floodplain (Agro-Ecological Zone No. 9) (UNDP and FAO, 1988). It is characterized by non-calcareous dark grey flood plain soil having $\mathrm{pH}$ value from 6.98 to 7.14 and the soil texture is silty loam. The relief of land is flat and above flood level and sufficient sunshine is available throughout the experiment period. The transplant aman rice cv. BRRI dhan49 a modern variety of rice was used as a test crop in this experiment. It is photosensitive and resistant to blast disease. The life cycle of this variety ranges from 100 to 135 days (BRRI, 2010). The seedlings were collected from Bangladesh Agricultural University Central Farm, Bangladesh Agricultural University, Mymensingh. It is usually produces a grain yield of 5-5.5 tha $\mathrm{t}^{-1}$ under proper management (DAE, 2013). The experiment was conducted in a Randomized complete block design (RCBD) with three replications. There were four different treatments viz. $\mathrm{T}_{0}$ : Recommended fertilizer dose, $\mathrm{T}_{1}: 5 \mathrm{t} / \mathrm{ha}$ ipil-ipil tree green leaf biomass (500 g/plot), $\mathrm{T}_{2}: 7.5$ $\mathrm{t} / \mathrm{ha}$ ipil-ipil tree green leaf biomass $(750 \mathrm{~g} / \mathrm{plot})$ and $\mathrm{T}_{3}: 10 \mathrm{t} / \mathrm{ha}$ ipil-ipil tree green leaf biomass $(1000 \mathrm{~g} / \mathrm{plot})$. The treatments were randomly distributed to the unit plots in each block. The total number of plots was 12 . The unit plot size was $1 \mathrm{~m} \times 1 \mathrm{~m}$. The spacing between blocks was $100 \mathrm{~cm}$ and the plots were separated from each other by $40 \mathrm{~cm}$. The selected ipil-ipil (Leucaena leucocephala) tree green leaf biomass was collected from Bangladesh Agricultural University campus, Mymensingh and tree leaf biomass was chopped by hand and incorporated to the experimental plots soil after 15 days of transplanting of rice seedlings. Thirty three days old seedlings were transplanted with $25 \times 15 \mathrm{~cm}$ spacing. Two or three healthy seedlings per hill were transplanted in all the plots. After transplanting, necessary intercultural operations were done as required. The rice plants were harvested on 9 December, 2014 at its full maturity when $90 \%$ of the grains became golden yellow in colour.

The data collection for studied plant parameters, five hills were randomly selected and carefully uprooted from each unit plot to record yield and yield contributing characters like plant height, total tillers/hill, effective tillers/hill, non-effective tillers/hill, panicle length, number of grains/panicle, 1000-grain weight, grain and straw yield, biological yield and harvest index (\%). After plant sampling, the whole plots were harvested and necessary information recorded accordingly. Grain and straw yields were recorded plot wise and expressed as tha $^{-1}$. For studied soil chemical properties, an initial soil sample was collected before ipil-ipil tree green leaf biomass incorporation. Another soil samples were collected from the experimental plots at 30 days after incorporation of ipil-ipil leaf biomass or 15 days after transplanting of rice and after harvesting of rice. The soil samples were analyzed to determine the soil chemical properties like organic matter, total $\mathrm{N}$, available $\mathrm{P}$, exchangeable $\mathrm{K}$ and available $\mathrm{S}$ before and after incorporation of ipil-ipil tree green leaf biomass in experimental plots. Organic matter content of soil samples were estimated following the method developed by Walkey and Black (1934). The total $\mathrm{N}$, available $\mathrm{P}$, exchangeable $\mathrm{K}$ and available $\mathrm{S}$ were determined by following semi-micro Kjeldhal method, modified Olsen method, ammonium acetate $\left(\mathrm{NH}_{4} \mathrm{OAc}\right)$ extraction method and turbidimetric method, respectively described by Page et al. (1989). The collected data both plant and soils were tabulated and analyzed through a standard computer package statistical procedure WASP. The means were ranked by Duncan's New Multiple Range Test (DMRT) (Gomez and Gomez, 1984).

\section{RESULTS}

\section{Effect of different doses of ipil-ipil tree green leaf biomass on yield and yield contributing characters of rice cv. BRRI dhan49}

\section{Plant height}

The tallest $(117.79 \mathrm{~cm})$ plant height was produced from the treatment $T_{3}$ which was $10 \mathrm{t} / \mathrm{ha}$ ipil-ipil tree green leaf biomass and the lowest $(104.48 \mathrm{~cm})$ plant height was observed in the treatment of $5 \mathrm{t} /$ ha ipil-ipil tree green leaf biomass. The recommended fertilizer dose produced $114.78 \mathrm{~cm}$ plant height which was second highest (Table 1). 


\section{Total tillers hill-1}

Application of different doses of ipil-ipil leaf biomass had significant effect on the production of number of total tillers hill ${ }^{-1}$. The highest number (13.07) of total tillers per hill was produced in the treatment $\mathrm{T}_{3}$ and the lowest (9.20) was produced by the treatment $T_{1}$. The recommended fertilizer dose produced second highest (12.27) total tillers hill $^{-1}$ which was statistically similar to the treatment $T_{3}$. From the results it is appeared that the increasing dose of ipil-ipil tree green leaf biomass produced highest number of total tillers per hill compared to the recommended fertilizer dose (Table 1).

\section{Effective tillers hill $^{-1}$}

The number of effective tillers per hill increased consistently and significantly with the incorporation of different doses of ipil-ipil leaf biomass. Among the different treatments of ipil-ipil leaf biomass the treatment of $10 \mathrm{t} / \mathrm{ha}$ ipil-ipil tree green leaf biomass gave the highest (12.27) number of effective tillers per hill which was statistically similar to the treatment of recommended fertilizer dose. On the other hand, the lowest (8.73) number of effective tillers per hill was produced from the treatment of 5 t/ha ipil-ipil tree green leaf biomass (Table 1).

\section{Non-effective tillers hill $^{-1}$}

The different doses of ipil-ipil tree green leaf biomass were not significantly affected on the production of noneffective tillers per hill. The highest (0.67) number of non-effective tillers per hill was observed from the treatment $T_{3}$ and the lowest $(0.27)$ number of non-effective tillers per hill was observed from the treatment $T_{2}$ (Table 1).

\section{Panicle length}

Different doses of ipil-ipil tree green leaf biomass had significant effect on panicle length. However, the longest $(28.95 \mathrm{~cm})$ panicle was obtained from the treatment $T_{3}$ which was $10 \mathrm{t} /$ ha ipil-ipil tree green leaf biomass and the shortest $(26.15 \mathrm{~cm})$ panicle length was obtained in the treatment $T_{1}$ which was $5 \mathrm{t} /$ ha ipil-ipil tree green leaf biomass. The result revealed that the increasing dose of ipil-ipil tree green leaf biomass was gradually increased the highest panicle length (Table 1).

\section{Number of grains panicle ${ }^{-1}$}

The number of grains panicle ${ }^{-1}$ of rice cv. BRRI dhan49 was significantly affected by the different treatments of ipil-ipil tree green leaf biomass. The number of grains panicle ${ }^{-1}$ ranged from 109.31 to 77.05 where the highest (109.31) number was obtained from the treatment of recommended fertilizer dose which was statistically similar with the treatment $T_{3}$. On the other side, the treatment $T_{1}$ was produced the lowest (77.05) grains per panicle which was statistically similar to the treatment $\mathrm{T}_{2}$ (Table 1).

\section{0-grain weight}

The results revealed that there was a significant relationship between the 1000-grain weight and different treatments of ipil-ipil leaf biomass. The highest $(15.23 \mathrm{~g}) 1000$-grain weight was obtained from the treatment of recommended fertilizer dose. Among the different treatments of ipil-ipil tree green leaf biomass the highest $(13.38 \mathrm{~g}) 1000$-grain weight obtained from the treatment of $10 \mathrm{t} / \mathrm{ha}$ and the lowest $(12.84 \mathrm{~g})$ was in the treatment of $5 \mathrm{t} /$ ha ipil-ipil tree green leaf biomass (Table 1 ).

\section{Grain yield}

The effect of different doses of ipil-ipil tree green leaf biomass on transplant aman rice cv. BRRI dhan49 revealed a significant variation among the various treatments. The result showed that the highest $(5.29 \mathrm{t} / \mathrm{ha})$ grain yield was obtained from the recommended fertilizer dose treatment. Among the different doses of ipil-ipil tree green leaf biomass it was observed that the highest dose (10 t/ha) performed the better (4.80 t/ha) grain yield. Other treatments such as $7.5 \mathrm{t} / \mathrm{ha}$ and $5 \mathrm{t} / \mathrm{ha}$ of ipil-ipil tree green leaf biomass were produced $3.16 \mathrm{t} / \mathrm{ha}$ and 2.36 t/ha grain yield, respectively (Table 1 ). 


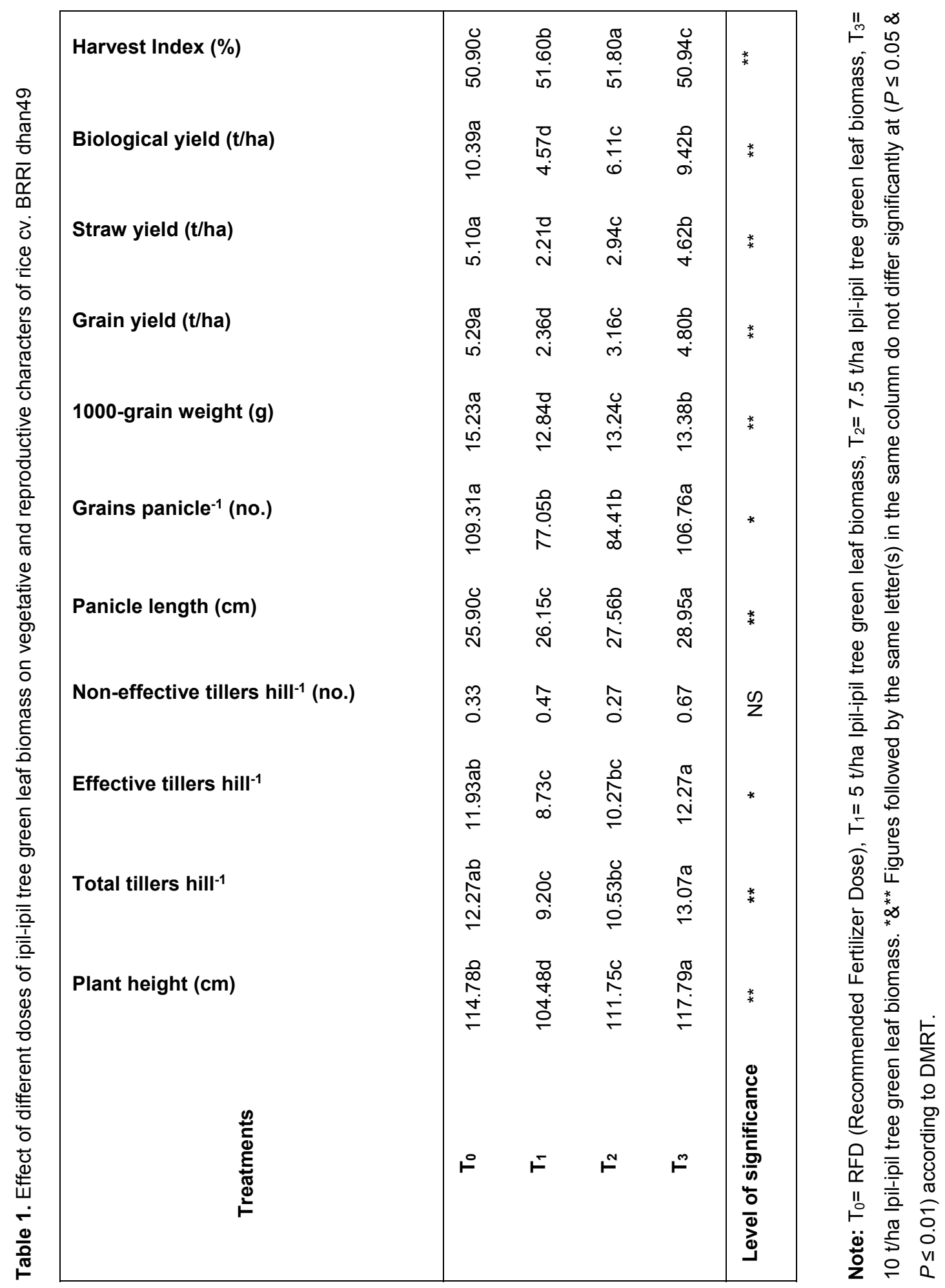

\section{Straw yield}

The straw yield of rice was significantly influenced by the addition of ipil-ipil tree green leaf biomass (Table 1). The result revealed that the highest $(5.10 \mathrm{t} / \mathrm{ha})$ straw yield was recorded from the treatment $T_{3}$ while the 
lowest $(2.21 \mathrm{t} / \mathrm{ha})$ was produced by the treatment $T_{1}$. It was also noted that the next highest $(4.62 \mathrm{t} / \mathrm{ha})$ straw yield was obtained from the recommended fertilizer dose treatment. The results of the ANOVA revealed that there was significant difference $(p \leq 0.01)$ in the straw yield of rice across the different doses of ipil-ipil tree leaf biomasses (Table 1).

\section{Biological yield}

The ANOVA results revealed that the biological yield of rice was significantly $(p \leq 0.05)$ influenced by the incorporation of various amount of ipil-ipil tree leaf biomass (Table 1). The highest (10.39 $\mathrm{t} / \mathrm{ha}$ ) biological yield was found from the treatment $10 \mathrm{t} / \mathrm{ha}$ ipil-ipil tree green leaf biomass while the lowest $(4.57 \mathrm{t} / \mathrm{ha})$ was found in the treatment $5 \mathrm{t} /$ ha ipil-ipil tree green leaf biomass (Table 1 ).

\section{Harvest index}

Harvest index was significantly influenced by different doses of ipil-ipil tree green leaf biomass (Table 1). The result showed that the highest $(51.80 \%)$ harvest index was obtained from the treatment $7.5 \mathrm{t} / \mathrm{ha}$ ipil-ipil tree green leaf biomass while the lowest was found in the treatment $\mathrm{T}_{1}$ which was statistically similar to the treatment $T_{3}$ (Table 1). The results of the ANOVA revealed that there was significant difference $(p \leq 0.01)$ in the harvest index of rice across the different doses of ipil-ipil tree green leaf biomasses (Table 1).

\section{Effect of ipil-ipil tree green leaf biomass on some important essential nutrients at 30 days after incorporation and post harvest soils}

\section{Total $\mathbf{N}$}

Ipil-ipil tree green leaf biomass released an influential amount of nitrogen in soil at 30 days after incorporation (Table 2). The result revealed that the release of total $\mathrm{N}$ from ipil-ipil leaf biomass at 30 days after incorporation varied from $0.191 \%$ to $0.163 \%$ due to the different treatments. The treatment $T_{3}$ which was $10 \mathrm{t} / \mathrm{ha}$ ipil-ipil tree green leaf biomass released highest $(0.191 \%)$ amount of nitrogen in the rice field soils while the lowest $(0.163 \%)$ amount of nitrogen released from recommended fertilizer dose. In the initial soil sample it was found that total nitrogen content is $0.140 \%$ (Table 2). On the other hand, the incorporation of ipil-ipil tree green leaf biomass in the rice field also significantly influenced on total $\mathrm{N}$ content in the post harvest soils (Table 2). After harvesting of rice, total $N$ content varied from $0.178 \%$ to $0.153 \%$ in post harvest soils. The highest total $\mathrm{N}$ content was $0.178 \%$ found in the treatment $\mathrm{T}_{3}$ which was statistically similar to the treatment $\mathrm{T}_{2}$ and $\mathrm{T}_{1}$. The lowest total $\mathrm{N}$ content was $0.153 \%$ found in recommended fertilizer dose (Table 2).

\section{Available $\mathbf{P}$}

The incorporation of different doses of ipil-ipil tree green leaf biomass in the experimental field was significantly influenced on the release of available $P$ (Table 2). After 30 days of incorporation of ipil-ipil tree green leaf biomass, the treatment $T_{3}$ which was $10 \mathrm{t} /$ ha ipil-ipil tree green leaf biomass released the highest (30.71 ppm) amount of available $P$ and the lowest $(19.13 \mathrm{ppm}$ ) amount of available $\mathrm{P}$ released from the treatment $T_{1}$ which was $5 \mathrm{t} /$ ha ipil-ipil tree green leaf biomass. In the initial soil sample the amount of available $\mathrm{P}$ was $26.18 \mathrm{ppm}$. The recommended fertilizer dose released $30.18 \mathrm{ppm}$ of available $\mathrm{P}$ in the experimental soils (Table 2). The available $P$ was also significantly influenced due to the different treatments of ipil-ipil tree green leaf biomass in post harvest soils (Table 2). The highest amount of available P was 29.14 ppm found in the recommended fertilizer dose treatment. Among the different doses of ipil-ipil tree leaf biomass, the amount of available phosphorus was gradually increased with the increase of doses. According to the result it was found that post harvest soils contained $28.86 \mathrm{ppm}, 20.92 \mathrm{ppm}$ and $17.44 \mathrm{ppm}$ available $\mathrm{P}$ from the treatment of $10 \mathrm{t} / \mathrm{ha}, 7.5 \mathrm{t} / \mathrm{ha}$ and $5 \mathrm{t} / \mathrm{ha}$ ipil-ipil tree green leaf biomass, respectively (Table 2).

\section{Exchangeable $\mathrm{K}$}

Exchangeable $\mathrm{K}$ content in soil was greatly influenced with the application of ipil-ipil tree green leaf biomass at different growth stages of rice (Table 2). After 30 days of incorporation of ipil-ipil tree green leaf biomass, the treatment $\mathrm{T}_{3}$ released the highest (83.52 ppm) amount of exchangeable $\mathrm{K}$ and the lowest (69.24 $\mathrm{ppm}$ ) in the treatment $\mathrm{T}_{1}$. The amount of exchangeable $\mathrm{K}$ in the initial soil sample was $77.40 \mathrm{ppm}$ (Table 2). Exchangeable $\mathrm{K}$ content was also significantly influenced by the different treatments of ipil-ipil tree green leaf 
biomass in post harvest soils (Table 2$)$. The highest $(77.42 \mathrm{ppm}$ ) amount of available $\mathrm{P}$ of post harvest soils found in treatment $T_{3}$ and the lowest in the treatment $T_{1}$ which was $67.56 \mathrm{ppm}$. The second highest and third highest content of exchangeable $\mathrm{K}$ of post harvest soils was recorded in the treatment $\mathrm{T}_{3}$ and recommended fertilizer dose which were $75.36 \mathrm{ppm}$ and $73.32 \mathrm{ppm}$, respectively (Table 2).

\section{Available Sulphur (S)}

Before the application of ipil-ipil tree green leaf biomass in the experimental plots the amount of available $\mathrm{S}$ was $8.92 \mathrm{ppm}$ in the initial soil sample (Table 2). After 30 days of incorporation of ipil-ipil tree green leaf biomass a significant increased in the amount of $S$ was observed after soil analysis. The highest amount of available $S$ was $26.05 \mathrm{ppm}$ found in the treatment $T_{3}$ and the lowest amount of available $S$ released from the treatment $\mathrm{T}_{1}$ which was $8.92 \mathrm{ppm}$ (Table 2 ). In post harvest soils, the amount of S significantly increased with the increase of doses of ipil-ipil tree green leaf biomass. The amount of available $S$ in post harvest soils was $7.83 \mathrm{ppm}, 7.50 \mathrm{ppm}, 5.35 \mathrm{ppm}$ and $6.43 \mathrm{ppm}$ from the treatment of $10 \mathrm{t} / \mathrm{ha}, 7.5 \mathrm{t} / \mathrm{ha}, 5 \mathrm{t} / \mathrm{ha}$ ipil-ipil tree green leaf biomass and recommended fertilizer dose, respectively (Table 2).

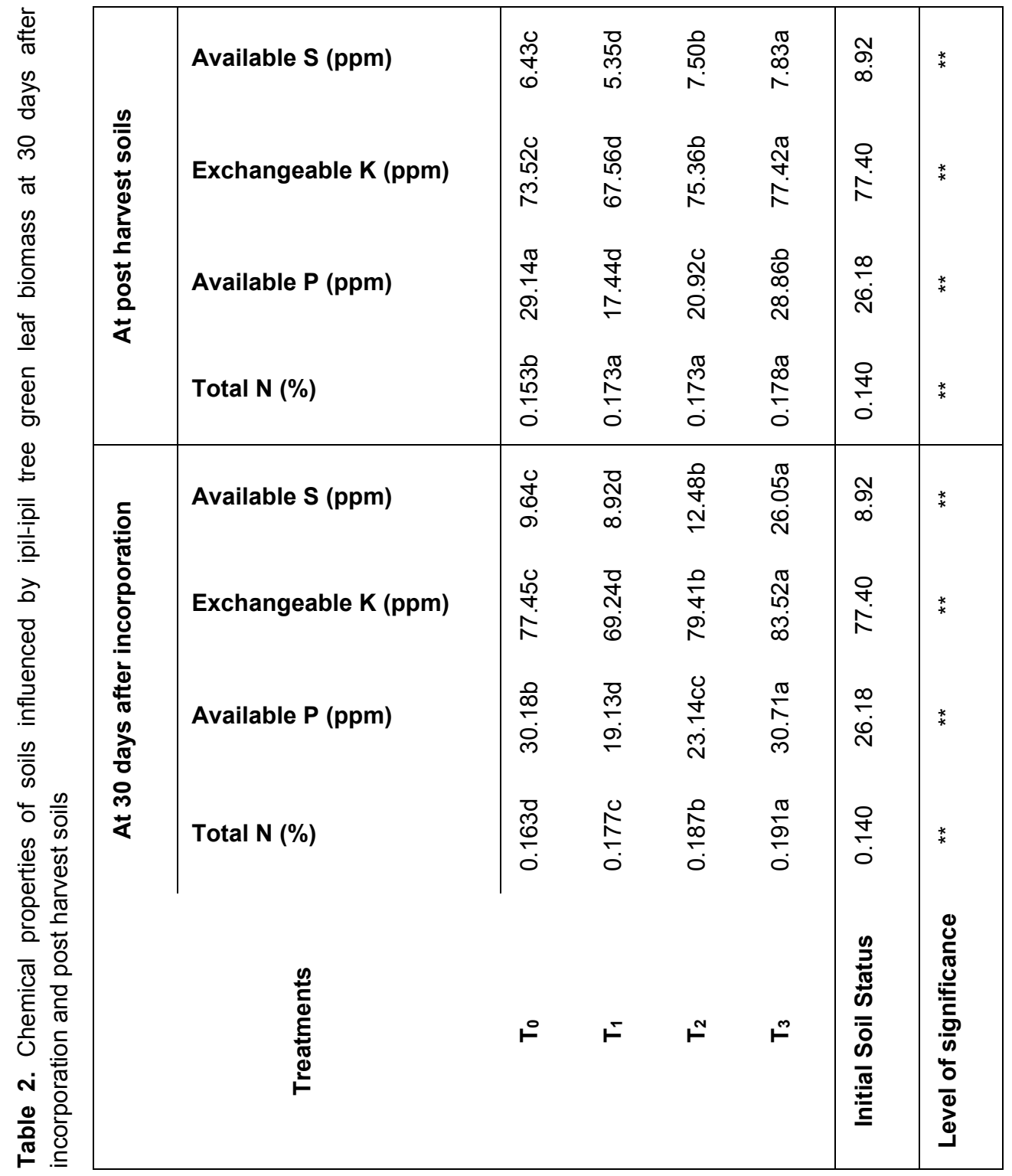




\section{DISCUSSION}

The present study showed that the different doses of ipil-ipil tree green leaf biomass were positively influenced on yield and yield contributing characters of rice cV. BRRI dhan49. From the results, it was found that the treatments had significant influence on plant height, total tillers hill ${ }^{-1}$, effective tillers hill ${ }^{-1}$, panicle length, grains panicle ${ }^{-1}$, 1000-grain weight, grain yield, straw yield, biological yield and harvest index. However, the treatments had no significant effect on non-effective tillers hill ${ }^{-1}$. The highest (5.29 $\left.\mathrm{t} / \mathrm{ha}\right)$ grain yield was obtained from recommended fertilizer dose treatment and the lowest (2.36 t/ha) grain yield was recorded in the treatment $T_{1}$. Among the different doses of ipil-ipil tree green leaf biomass, the treatment $T_{3}$ produced the highest and overall second highest (4.80 t/ha) grain yield. The above results were supported by previous findings of Apostol (1989), Zoysa et al. (1990), Akter et al. (1993) and Nahar et al. (1996). Apostol (1989) stated that organic and inorganic fertilizer produced higher length of panicle, productive tillers per hill and grain index of rice. Zoysa et al. (1990) reported that incorporation of Leucaena green manure increase $\mathrm{N}$ uptake throughout the vegetative period and increased grain yield of rice significantly. Nahar et al. (1996) cited that green manure with Leucaena leucocephala produced highest grain yield which was 4.36 t/ha whereas fertilized (100 kg N/ha) plots produced $4.12 \mathrm{t} / \mathrm{ha}$ grain yield of rice. Akter et al. (1993) cited that application of green manure plus chemical fertilizer produced significantly higher yield parameters of rice. Hossain et al. (2007) reported that tree litter application had a significant positive effect on the yield parameters of rice such as plant height, panicle length, tillers per hill, filled grain, 1000-grain weight, and the addition of tree litter to inorganic fertilizer produced significantly higher yield than inorganic fertilizers solely which was fully supported the results of this experiment.

Here, the results also showed that the nutrient status of soils such as organic matter, total $N$, available $P$, exchangeable $\mathrm{K}$ and available Sulphur were positively affected by incorporation of ipil-ipil tree green leaf biomass. The amount of organic matter, total $N$, available $P$, exchangeable $K$ and available Sulphur was higher in the ipil-ipil tree green leaf biomass treatments than recommended fertilizer dose treatment. Among the different doses of ipil-ipil leaf biomass the treatment of $10 \mathrm{t} / \mathrm{ha}$ ipil-ipil tree green leaf biomass showed better performance in releasing nutrients than others. The uptake of $N, P, K$ and $S$ was higher in the treatment of $10 \mathrm{t} / \mathrm{ha}$ ipil-ipil tree green leaf biomass over the treatments of $7.5 \mathrm{t} / \mathrm{ha}$ and $5 \mathrm{t} / \mathrm{ha}$ ipil-ipil tree green leaf biomasses. Guan (1989) found that the available N and P content in soil sample taken from plots with the application of organic materials were significantly higher than control which was strongly supportive to the present findings. These results also in agreement with that of Haque et al. (2001) reported that a positive improvement in soil fertility from the application of tree pruning's. This result is also similar to the Maharudrappa et al. (2000) where they reported that the application of tree litter enhanced nutrient availability in soils. These result also in agreement with that of Das and Chaturvedi (2003) who reported that the highest decomposition rate was observed in leaf litter Leucaena leucocephala followed by Sesbania grandiflora, Dalbergia sissoo and Eucalyptus tereticornis. The release of nutrients like $\mathrm{N}, \mathrm{P}, \mathrm{K}$ was higher in Leucaena leucocephala. The species having highest $\mathrm{N}$ percentage showed the fastest decomposition rate. Hossain et al. (2007) found the similar type of results in their study where they reported that Ipil-Ipil (Leucaena leucocephala) and Mander (Erythrina orientalis) was the best in building organic matter and total $\mathrm{N}$ content over the control plots which treated by recommended fertilizer doses. Mojumder et al. (2008) reported that the addition of leaf biomass slightly increase the amount of total $\mathrm{N}$, available $\mathrm{P}$, exchangeable $\mathrm{K}$ and $\mathrm{S}$ in soil over recommended fertilizer dose which also supports the results of this experiment.

\section{CONCLUSION}

From the experiment it was revealed that the recommended fertilizer dose gave only the highest grain yield of rice over ipil-ipil tree green leaf biomass treatments but soil nutrient contents, growth parameters values were lowest in this treatment. Among the different doses of ipil-ipil tree green leaf biomasses, it was found that the increased dose of ipil-ipil leaf biomass were positively increased the studied parameters of rice. However, it seems that the ipil-ipil tree green leaf biomass i.e. higher dose $10 \mathrm{t} / \mathrm{ha}$ has significant impacts on rice production and would be possible to substitute of or apply in combination with inorganic fertilizer although 
there was some yield loss $(10.21 \%)$ which was less significant compare to recommended fertilizer. Tree leaf biomass is an important source of essential nutrients which enhances the soil fertility. It is environmentally friendly because the rapid decomposition and the highest residual effect of tree leaf biomasses. Therefore, it can be suggested that for rice production we can use tree leaf biomass as a source of organic matter which is available in agroforestry system, significantly reduces the considerable amount of chemical fertilizer.

\section{ACKNOWLEDGEMENTS}

The authors would like to acknowledge giving the financial support from the authority of National Science and Technology (NST) to conduct this research work.

\section{REFERENCES}

1. Akter MS, MKS Hasan, RC Adhikery and MK Chowdhury, 1993. Integrated management of Sesbania rostrata and urea-nitrogen in rice under a rice-rice cropping system. Annual Bangladesh Agriculture, 3: 189114.

2. Ansari HA, 2006. Effect of different tree biomass and their time of incorporation on the fertility of soil and productivity of BR11 rice. M.S. Thesis, Department of Agroforestry, Bangladesh Agricultural University, Mymensingh.

3. Apostol EDF, 1989. Influence of mirasoil organic and X-rice liquid fertilizer in combination with inorganic fertilizer on IR66 and IR12 rice varieties. Malabeu, Metro Manila, Philippines.

4. Arifin MSA, BN Tanzi, MA Habib, MA Mondol and MA Wadud, 2012. Effect of green leaf biomass application of different trees on the yield of rice. Journal of Agroforestry and Environment, 6: 27-31.

5. BARC (Bangladesh Agricultural Research Council), 2000. Fertilizer Recommendation Guide-2000. Farmgate, Dhaka.

6. BRRI (Bangladesh Rice Research Institute), 2010. Manual-Adhunik Dhner Chash.

7. DAE (Department of Agriculture Extension), 2013. BRRI dhan49. Available at: http:// www. ViewPage_Crop_Production_Technology.aspx.htm.

8. Das DK and OP Chaturvedi, 2003. Litter quality effects on decomposition rates on forestry plantations. Tropical Ecology, 44: 259-262.

9. Dil Atia Parvin, TM Zakaria, MK Hasan and GMM Rahman, 2007. Effect of leaf biomass of different agroforest trees on the prevalence of insects and yield of rice cv. BR11. Journal of Agroforestry and Environment, 1: 59-62.

10. Gomez KA and AA Gomez, 1984. Duncan's Multiple Range Test. Statistical Procedure for Agricultural Research. $2^{\text {nd }}$ edition, A Wiley Inter-Science Publication, Johan and Sons, New York, pp: 202-215.

11. Gordon JC and CT Wheeler, 1983. Biological nitrogen fixation in forest ecosystems: foundations and applications. Martinus Nijhoff/Dr. W. Junk Publishers, The Hague, Netherlands, p. 312.

12. Guan SY, 1989. Effect of organic manures on soil enzyme activities and N and P transformation. Acta Pedolotica Sinica, 26: 72-78.

13. Haque MA, MI Ali and MK Khan, 2001. Effect of tree pruning on soil fertility system. Pakistan Journal of Biological Science, 4: 647-650.

14. Hasan MK, GMM Rahman and MM Rahman, 2007. Effect of tree leaf biomass on the performance of rice cv. BR11 and subsequent soil health. Journal of Agroforestry and Environment, 1: 7-10.

15. Hasan MM, 2014. Performance of Kangkong and Indian spinach in ipil-ipil based alley cropping system. M.S. Thesis, Department of Agroforestry, Bangladesh Agricultural University, Mymensingh.

16. Hossain KL, MA Wadud and E Santosa, 2007. Effect of Tree Litter Application on Lowland Rice Yield in Bangladesh. Bulletin: Agronomy, 35: 149-153.

17. Khan TA, 2009. Effect of tree leaf litter on the yield and yield contributing characters of $T$. aman rice cV. BR 11. M.S. Thesis, Department of Agroforestry, Bangladesh Agricultural University, Mymensingh.

18. Maharudrappa A, CA Srinivasamurthy, MS Nagaraj, R Siddaramappa and HS Anand, 2000. Decomposition rate of litter and nutrient release pattern in a tropical soil. Journal of the Indian Society of Soil Science, 48 : 92-97.

19. Mojumder MO, GMM Rahman, M Begum, MM Rahman and MSI Majumder, 2008. Effect of different forms of Teak leaf biomass on the yield of rice and nutrient release in the soil. Journal of Agroforestry and Environment, 2: 1-6. 
20. Mondol MA, KK Islam, MH Rashid, O Farruk and GMM Rahman, 2007. Residual effect of plant biomass on the performance of mustard. Journal of Agroforestry and Environment, 1: 63-66.

21. Mwase W, A Sefasi, J Njoloma, BI Nyoka, D Manduwa and J Nyaika, 2015. Factors Affecting Adoption of Agroforestry and Evergreen Agriculture in Southern Africa. Environment and Natural Resources Research, 5: 148.

22. Nahar K, J Haider and AJMS Karim, 1996. Effect of organic and inorganic nitrogen sources on rice performance and soil properties. Bangladesh Journal of Botany, 25: 73-78.

23. Page AL, RH Miller and DR Keeny, 1989. Methods of soil analysis. Part-2, $2^{\text {nd }}$ edition. American Society of Agronomy, Inc. Publication, Madison, Wisconsin, USA.

24. Palm CA, CN Gachengo, RJ Delve, G Cadisch and KE Giller, 2001. Organic inputs for soil fertility management in tropical agro ecosystems: application of an organic resource database. Agriculture Ecosystems and Environment, 83: 27-42.

25. Place F, M Adato, $P$ Hebinck and M Omosa, 2003. The Impact of Agroforestry-Based Soil Fertility Replenishment Practices on the Poor in Western Kenya. FCND Discussion Paper No. 160. International Food and Policy Research Institute, Washington, D.C.

26. Rijpma $\mathrm{J}$ and $\mathrm{M}$ Jahiruddin, 2004. National strategy and plan for use of soil nutrient balance in Bangladesh. A consultancy report SFFP, Khamarbari, Dhaka. Sustainable environment development. Asia Pacific Journal of Environmental Development, 1: 48-67.

27. Sarkar UK, BK Saha, C Goswami and MAH Chowdhury, 2010. Leaf litter amendment in forest soil and their effect on the yield quality of red amaranth. Journal of Bangladesh Agricultural University, 8: 221-226.

28. Satter MA, 2002. Build up organic matter in soil for sustainable agriculture. In: Panorama, The Independent, October 25. p. 10.

29. Tanzi BN, MSA Arifin, MA Mondol, AK Hasan and MA Wadud, 2012. Effect of tree leaf biomass on soil fertility and yield of rice. Journal of Agroforestry and Environment, 6: 129-133.

30. Uddin MR, 2004. Effect of tree litter as green manure on foliar diseases and yield of rice. M.S. Thesis, Department of Agroforestry, Bangladesh Agricultural University, Mymensingh.

31. UNDP and FAO, 1988. Plant Resources Appraisal of Bangladesh for agricultural development. Report-2. Agro-ecological regions of Bangladesh. UNDP, FAO, Rome, p. 116.

32. Walkley A and IA Black, 1934. An examination of Degtjareff method for determining soil organic matter and proposed modification of the chromic acid titration method. Soil Science, 37: 29-38.

33. Zoysa AKN, G Keerthisinghe and SH Upasena, 1990. Effect of Leucaena leucocephala (Lam.) de Wit. as green manure on nitrogen uptake on nitrogen uptake and yield of rice. Biological Fertility Soils, 9: 68-70. 